\title{
Identification, determine and control of health, safety, and environmental hazards associated with the construction projects: State-Of-The-Art
}

\author{
Khosro Zehro \\ Faculty of Civil and Environmental Engineering, Near East University, Nicosia, Mersin10, Turkey
}

\section{ARTICLE INFO}

\section{ARTICLE HISTORY:}

Received: 18 April 2020

Revised: 04 May 2020

Accepted: 06 May 2020

Published: 1 July 2020

\section{KEYWORDS:}

Health and safety, safety management, hazards, construction projects, workplace

\begin{abstract}
A B S T R A C T
The industry of construction is considered a strong economic factor and one of the most dangerous industries. This industry involves a wide range of activities that subject all employees from experts to non-skilled workers to intense undesired situations. Everybody is vulnerable to the hazards, risks, and dangers of this massive industry. Insufficient health and safety management, damage to construction, and constructed environments can also lead to increased accidents and injuries. Accidents not only have consequences of significant suffering and pain, but they are also marginalizing efficiency, time, productivity, negatively impact the environment and overall adding the construction costs. The results of the study will help to identify the essential factors that cause rising rates of risks in construction projects. By identifying these causes, emphasis on environmental, health and safety management will help in implementing awareness to all of those participating in the construction projects. This study demonstrates the criteria and guidelines for the identification, to determine the controlling environmental effects and health and safety hazards at construction project worksites. Furthermore, attempt to explain the techniques of decreasing hazards by the development of pre-construction planning and provide adequate controlling equipment for executing a safer, more profitable construction project from start to the end. Also, in the study suggestions are given for management that they must provide adequate health and safety training for the entire workforce, a supervised workplace by professional site safety managers and operators that will attempt to reduce health and safety hazards at sites.
\end{abstract}

\section{INTRODUCTION}

Construction project sites are a very significant sector since a vast number of employees are engaging activities in construction. Construction site employees can divide into three categories; "Technical and managerial", "Professional", and "Unskilled". All three types are at risk of accidents, death, or related hazards on the construction project sites. Construction project site workers typically face undesirable dangers of accidents at work (Almen et al., 2012). Compared to many industries, the construction sector is complex and unique. Such complexities cause the construction industry to become the most unsafe industry, which can lead to high accident rates (Pungvongsanuraks et al., 2010). Health and safety were also specified as one of the significant factors that influence project managers and corporations.
Efficient safety management designed to keep the protection of the environment, to make safety in the workplace activities and to make staff aware of their health. In previous decades, safety has been considered by many developing countries as one of the most valuable management subjects of construction executions (Chen et al., 2011).

Hazard identification on construction sites mainly depends on human observation (Reese \& Eidson, 2006). Occasionally, safety management neglect to determine hazards because of their significant number, making it more challenging to review every area to determine hazards (Kim et al., 2015). Therefore, all projects require health and safety planning, which are designed and documented utilizing identification, the determining and controlling possible risks 
in the workplace are essential, especially in uncontrolled environmental hazards (Sawyer \& Martin, 2000). The documented health and safety programs in projects must have to be updated regularly as new valuable information is discovered.

From a survey done by Pheng and Shiua (2000), they showed that more than $80 \%$ of the constituents either found it difficult to identify and assess hazards, also to execute the required control measurements. These survey results also corroborated with the empirical outcomes of a Solomone (2008) analysis. It presents the importance of such mechanisms to develop and indicates how environmental impacts and elements of health and safety can be accepted as part of the design, scheduling, and implementation in construction projects (Gangolells et al., 2011). Therefore, additional techniques and tools are also required to support architects and construction engineers with identifying hazards and optimizing designs (Gambatese, 2008). The primary aim of this study is to enhance the process of introducing environmental, health and safety programs in building construction implementation companies.

\section{METHODOLOGY}

Management of hazards is an essential aspect of all management programs, and it should establish the main characteristics of health, safety, and environmental hazards.

Table 1. Some approaches to identifying hazards in construction projects

\begin{tabular}{|l|l|}
\hline Author & Description \\
\hline $\begin{array}{l}\text { Albert et al. } \\
\text { (2014) }\end{array}$ & $\begin{array}{l}\text { Workers training to better } \\
\text { identifying hazards }\end{array}$ \\
\hline $\begin{array}{l}\text { Carter and } \\
\text { Smith (2006) }\end{array}$ & $\begin{array}{l}\text { Using a central database of health and } \\
\text { safety that includes safety-related data and } \\
\text { can be used to control the construction } \\
\text { process, risks, and relationships }\end{array}$ \\
\hline $\begin{array}{l}\text { Ismail and } \\
\text { Ghani }\end{array}$ & $\begin{array}{l}\text { They explained how all three site monitors, } \\
\text { the engineer, operations manager, and the } \\
\text { health and safety officer, play an essential } \\
\text { role in alerting all hazards that lead to } \\
\text { accidents. }\end{array}$ \\
\hline $\begin{array}{l}\text { Kim et al. } \\
(\mathbf{2 0 1 5})\end{array}$ & $\begin{array}{l}\text { By using the BIM programs, they } \\
\text { introduce an automatic discovery program } \\
\text { (on recent accident), which can search } \\
\text { automatically for the same accident } \\
\text { instances. }\end{array}$ \\
\hline $\begin{array}{l}\text { Matthew et } \\
\text { al. (2013) }\end{array}$ & $\begin{array}{l}\text { Identification and determine safety } \\
\text { monitoring elements clearly, and resource } \\
\text { demands have been demonstrated for } \\
\text { assessment, supervising, and responding. }\end{array}$ \\
\hline $\begin{array}{l}\text { Ophir et al. } \\
(\mathbf{2 0 1 0})\end{array}$ & $\begin{array}{l}\text { Evaluation of expected loss-of-control } \\
\text { injuries for precise steps of commonly } \\
\text { executed construction projects activities. }\end{array}$ \\
\hline
\end{tabular}

Besides that, hazard-management processes (hazard identification, hazards determination, and hazard control) are equivalent in either the environmental and health and safety areas. The concept of hazards refers similarly to risks on the lives, health of workers, the population around the sites and the environment.

As illustrated in some recent studies, the probability of an injury or accident established by controlling the necessary health and safety hazards and by using different strategies, they emphasize the employees' unsafe working conditions in the workplace. Table 1, summarizes some studies and their objectives. There are some gaps in knowledge about the relationship between specific activities of workers and the occurrence of hazards on some construction projects workplace.

\section{OBJECTIVE}

The purpose of this study is to identify possible hazards through the construction worksite, plus to determine and control all risks that can lead workers to have accidents in construction activities. By establishing and evaluating the disruptions in some worker's usual reaction, we want to identify necessary information regarding hazards since these disruptions may result in some effects on the environment. Even so, they can happen carelessly without the occurrence of risks, for instance, in a healthy environment, carelessness or neglect can create unsafe situations. Besides, some hazards cause workers to have difficulty responding and many workers do not react to the same health and safety hazards.

\section{IDENTIFICATION OF POSSIBLE HAZARDS IN CONSTRUCTION SITES}

Two considerable hazards that are common in all construction workplaces are being reported (Abdul et al., 2003). Physical harm hazards often occur by devices like power access devices, scaffolding, ladders and excavation machinery. These accidents can involve direct injuries to the workers and, if intense, could even lead to death. Various kinds of mechanical energies, like vibration, harsh noise, temperature and radiation, may also lead to physical injuries. Chemical injury hazards identified in construction work are like welding gases, asbestos, solvents and paints (Rwamamara, 2007).

Some hazards have chronic consequences, while others are acute on worker's health, as described in Table 2. For instance, if a worker unintentionally breathed a small quantity of asbestos fibre, he will not consider the impact of this, since no immediate symptoms (acute impacts) are present. However, if the worker breathes the small amount of asbestos fibre for an extended period, the risk for developing asbestos relevant diseases (like lung cancer) 
might increase. Furthermore, chronic hazards include contact with corrosive products, skin allergens, and sanitizers (Vitharana et al., 2015).

Table 2. Some identified health and safety hazards

\begin{tabular}{|l|l|}
\hline Hazards' types & Examples \\
\hline \multirow{4}{*}{$\begin{array}{l}\text { Chronic health } \\
\text { and safety } \\
\text { hazards }\end{array}$} & $\begin{array}{l}\text { Corrosive resources (brick, concrete, } \\
\text { and acid) }\end{array}$ \\
\cline { 2 - 3 } & $\begin{array}{l}\text { Asbestos (ceiling tiles, isolation } \\
\text { board, and lagging pipe) }\end{array}$ \\
\cline { 2 - 3 } & $\begin{array}{l}\text { Physical hazards (heat, noise, } \\
\text { humidity, nuclear power stations } \\
\text { radiation, and also solar radiations) }\end{array}$ \\
\cline { 2 - 3 } Acute health & $\begin{array}{l}\text { Irritants and Skin sanitizers (alkalis, } \\
\text { bitumen, cement, and acids) }\end{array}$ \\
\hline \multirow{5}{*}{ and safety } & $\begin{array}{l}\text { Moving or carrying heavy equipment } \\
\text { or products, Lifting }\end{array}$ \\
\cline { 2 - 3 } & Roofing works \\
\cline { 2 - 3 } & Trenches for deep excavations \\
\cline { 2 - 3 } & Dangerous chemicals \\
\cline { 2 - 3 } & Ladder \\
\cline { 2 - 3 } & Machinery and stations, usage device \\
\cline { 2 - 3 } & Falling workers from heights \\
\cline { 2 - 3 } & Emergencies like fire \\
\hline
\end{tabular}

Work-associated respiratory problems, back trouble, head and neck disorders are specific health troubles with workers. Most of the health injury hazards identified as acute impacts are falling workers from heights and electrical shocks (Ismail \& Ghani, 2012).

\section{JOB SAFETY ANALYSIS}

The identification and determination of hazards is a critical step in managing health and safety. Job safety analysis (JSA) is a practical approach to identify and control risks in construction activities (Gopinath and Johansen, 2016). Due to Ophir et al. (2010) observation, the job safety analysis approaches involve three stages:

(1) Identification: Selecting a particular activity or job and analysing it into many steps and after that identifying any probable loss-in-control occurrences which that happen during the works.

(2) Determine: Analysing the relevant hazards level for the designated work incident.

(3) Control: Monitoring of the hazards by taking appropriate steps to minimize or remove the risks.

Many variables have a direct and indirect influence on the safety levels, which differ from one work site to another, which include the essence of training in worksite safety, environmental work conditions, weather, the use of protective facilities, and so more.

\section{METHODS TO CONTROL HAZARDS IN CONSTRUCTION SITE}

\subsection{Causes of poor health and safety}

The industry of construction suffers from poor health and safety planning, which involves a high amount of accidents and a high number of deaths. So, to improve these problems, hazard identification must become the primary safety managing process (Carter \& Smith, 2006). Some poor performances in identifying hazards are mainly due to a lack of facilities to constantly identify all risks in a technical construction environment. The lack of expertise or mechanisms to detect hazards will be another significant impact, as each construction worksite is unique and mostly contains hazards that are not specified in previous knowledge (Mitropoulos et al., 2005).

Moreover, by human identification capability, many health and safety hazards are not merely recognized; for instance, the variability of surface-level friction may lead to slipping and falling. However, these hidden abnormal hazards may not represent direct risks to any construction site worker as these would pose potential hazards with or without more factors that contributed to such susceptible workers (Albert et al., 2014).

\subsection{Health and safety training}

Workplace accidents are the results of the integration of exposure to hazards and workers behaviour. Workers' inability to detect hazards and the proper response is the leading cause of injuries. Construction organizations should invest equipment in risk identification training and tendencies to communicate procedures for an adequate response (Matthew et al., 2013).

Training for taking data about health and safety is essential in all construction companies and requires familiarization, detection of hazards, responsibilities and requirements in any area. The health and safety mechanism should contain the first aid training for all employees, and the manager should hold the certification of essential life support. All employees must contribute in a session describing the health and safety program, the duties of individuals and teams, vehicles, emergency mechanisms, and fire-arms (Michael et al., 2006).

\subsection{Safety system implementation and control}

Successfully managing a construction project means not only implementing it within the specified period or with a determined budget, but with optimal health and safety (Belel \& Muhmud, 2012). Also, it has become clear that implementing safety standards in construction projects is not an easy task, but it is possible.

Plenty of the reasons for poor construction site safety has been identified and grouped under health and safety 
equipment. They propose that corporate health management will enhance the organization's quality. Also, hazard identification is among the critical steps for health and safety management at construction project sites because the most uncontrollable risks come from undefined hazards (Zolfagharian et al., 2011). It suggested that the contractors for construction worksites must develop site health, provide an internal safety strategy for appropriate safety management, have specific training for health and safety for their employees and conduct regular safety discussions. These advised holding weekly organized staff meetings at the operations level, to either ensure safety precautions at the workplace, to always protect their labours with personal protective equipment (PPE).

Table 3. Methods to control construction site hazards

\begin{tabular}{|c|c|}
\hline Methods & Description \\
\hline $\begin{array}{l}\text { Equipment } \\
\text { for safety } \\
\text { protection }\end{array}$ & Continually supplying PPE for the workers. \\
\hline \multirow{6}{*}{$\begin{array}{l}\text { Managing } \\
\text { health and } \\
\text { safety }\end{array}$} & $\begin{array}{l}\text { Regular meetings for health and safety plan } \\
\text { discussion. }\end{array}$ \\
\hline & $\begin{array}{l}\text { Planning for short term and long terms } \\
\text { health and safety to ensure the required site } \\
\text { safety performance. }\end{array}$ \\
\hline & $\begin{array}{l}\text { They are enforcing standards and strategies } \\
\text { for health and safety. }\end{array}$ \\
\hline & $\begin{array}{l}\text { Documenting, assessing, and updating of } \\
\text { activity conditions }\end{array}$ \\
\hline & The suggestion of precautions. \\
\hline & Determine and analysis of risks \\
\hline \multirow{5}{*}{$\begin{array}{l}\text { Attitudes } \\
\text { of workers } \\
\text { on health } \\
\text { and } \\
\text { safety }\end{array}$} & $\begin{array}{l}\text { Explain knowledge about risk impacts for } \\
\text { workers would help increase efficiency and } \\
\text { reduce the risk related to construction } \\
\text { behaviours. }\end{array}$ \\
\hline & $\begin{array}{l}\text { Workers on the construction projects must } \\
\text { understand and try to fix hazardous } \\
\text { conditions and attitudes. }\end{array}$ \\
\hline & $\begin{array}{l}\text { Execute a health and safety inspection } \\
\text { weekly. }\end{array}$ \\
\hline & Incentive programs should develop. \\
\hline & $\begin{array}{l}\text { Carry out regular health and safety meetings } \\
\text { and training. }\end{array}$ \\
\hline
\end{tabular}

To display safety warnings posters and signs at the workplace, to carry out weekly safety control, to reward workers for their positive behaviour and to motivate workers using safety devices (El-Mashaleh et al., 2010). Besides, using mandatory enforcement techniques like fines, the most effective strategies are used to increase safety output in construction projects (Table 3 ).

The most significant factor affecting safety program success at worksites is safety assessment (Chia-Kung Lee \& Jaafar, 2012). It is most important to ensure that adequate training about health and safety inspection is awarded to the new worker at the construction projects.
It identified in many other studies that appropriate injuries control systems are dependent on exceptional attention to health and safety management, such as the profession of safety managers within the company, training of workers and daily communications between managers and workers. Geller (2001) explored a triad safety theory (see Fig. 1) should develop an extensive monitoring mechanism for three areas of "persons," "behaviour," and "environment."

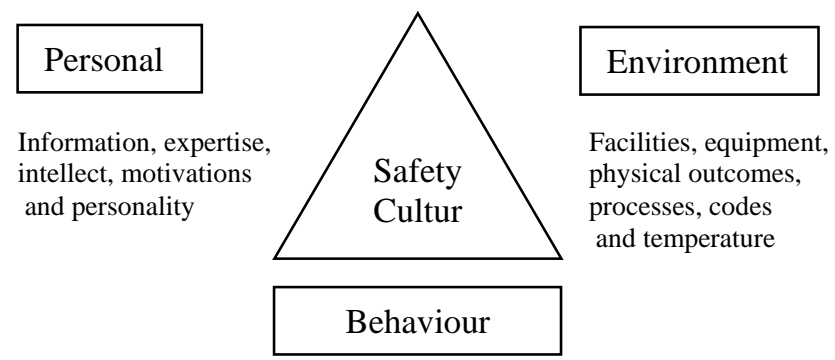

Conform, training, understanding, interacting and display "activity care."

Fig. 1. Geller's safety triad

The "persons" express a worker's eligibility, while the "behaviour" shows worker's attitudes to perform the work safely in a "particular environment." These three dimensions are relational and dynamic, and ultimately, the change in each variable will affect the other.

\section{CONCLUSIONS}

Preparing a mechanism to enhance the implementation of the health, safety, and environmental management system, plus minimizing accidents in construction projects should be the main task of any company, not just preparing documents on paper. This study demonstrates the criteria and guidelines for identification, to determine the controlling environmental effects and health and safety hazards at the construction project worksites. Furthermore, attempt to explain the techniques of decreasing hazards by the development of pre-construction planning and provide adequate controlling equipment.

In building construction job sites, health risks can be divided into two types: acute risks and chronic risks. Many of the acute risks recorded in projects are shocks by electricity and workers falling from heights. While most of the chronic risks recorded are exposure to hazardous materials. The main requirements for producing a safer worksite in construction projects are increasing professional safety managers with modern safety management and the execution of awareness techniques that should enforce and develop construction project workers to improve safety behaviours. The contractors should provide proper training about operating the devices before using any tools by the 
workers in their duties, which will help the workers' in accident prevention.

It is suggested that project management staff should eliminate the expected hazards in the pre-construction designing and planning stage. Also, to ensure that all necessary equipment for health and safety and hazard protection is procured and available for use in the right locations. Furthermore, present and complete Health and Safety training for the entire workforce. Finally, the supervision of site safety by expert managers, who have better safety control at construction workplaces.

\section{REFERENCES}

[1] Abdul Hamid, A. R., Wan Yusuf, W. Z., \& Singh, B. (2003). Hazards at construction sites, Proceeding of the 5th Asia-Pacific structural engineering and construction conference, Johor Bahru, Malaysia, 95104.

[2] Albert, A., Hallowell, M. R., \& Kleiner, B. M. (2014). Experimental field testing of real-time construction hazards identification and transmission techniques. Journal of construction engineering and management, 32(10), 1000-1016. https://doi.org/10.1080/01446193.2014.929721

[3] Almen, L., Larsson, T. J., \& Thunqvist, E. (2012). The influence of the designer on the risk of fallings from heights and of exposures to excessive workloads on two construction sites. Diva, Safety science monitor, 16(1), 2-7.

[4] Belel, Z. A., \& Muhmud, H. (2012). The safety culture of Nigerian construction workers. International journal of scientific and engineering research, 3(9), 1-5.

[5] Carter, G., \& Smith, S. D. (2006). Safety hazards identification on construction projects. Journal of construction engineering and management, 132(2), 197-205.

https://doi.org/10.1061/(ASCE)07339364(2006)132:2(197)

[6] Chen, W. T., Lu, C. S., \& Huang, Y., H. (2011). Investigating of safety cognition in Taiwan's construction personnel. Journal of marine science and technology, 19(4), 398-408. https://doi.org/10.1.1.471.4344/rep=rep1\&type=pdf

[7] Chia- Kung Lee, \& Jaafar' Y., (2012). Prioritization of factors influencing safety performance on construction sites: A study based on grade seven (G7) main contractors' perspectives. International conference on business, management, and governance (ICBMG 2012), Hong Kong, 6-12.

https://doi.org/10.7763/IPEDR. 2012. V57. 2

[8] El-Mashaleh, M. S., Al-Smadi B. M., Hyari, \& K. H., Rbabeh, S.M. (2010). Safety management in the Jordanian construction industry. Jordan journal of civil engineering, 4(1), 47-54.
[9] Gambatese, J. A. (2008). Research issues in prevention through design. Journal of safety research, 39(2), 153156.

https://doi.org/10.1016/j.jsr.2008.02.012

[10] Gangolells, M., Casals, M., Gassó, S., Forcada, N., \& Roca, X. (2011). Assessing concerns of interested parties when predicting the significance of environmental impacts related to the construction process of residential buildings. Building and environment-Science direct, 46(5), 1023-1037. https://doi.org/10.1016/j.buildenv.2010.11.004

[11] Geller, E. S., Bolduc, J. E., Foy, M. J., \& Dean, J. C. (2012). Actively caring for safety: Practical methods, empirical results, and provocative implications, $1^{\text {st }} \mathrm{ed}$., American society of safety engineers.

[12] Gopinath, V., \& Johansen, K. (2016). The risk assessment process for collaborative assembly: a job safety analysis approach. Science direct / Procedia CIRP, 44, 199-203. https://doi.org/10.1016/j.procir.2016.02.334

[13] Ismail, H. B., \& Ghani, K. D. A. (2012). Potential hazards at the construction worksite due to temporary structures. Procedia - Social and behavioral sciences, 49, 168-174. https://doi.org/10.1016/i.sbspro.2012.07.015

[14] Kim, H., Lee, H., Park, M., Chung, B., \& Hwang, S. (2015). Information retrieval framework for hazard identification in construction. Journal of computing in civil engineering, 29(3). https://doi.org/10.1061/(ASCE)CP.19435487.0000340

[15] Matthew R. Hallowell, A. M. ASCE, Jimmie W. Hinze, M. ASCE, Kevin C. Baud, \& Andrew Wehle, (2013). Proactive construction safety control: measuring, monitoring, and responding to safety leading indicators. Journal of construction engineering and management, 139(10), 1-8.

https://doi.org/10.1061/(ASCE)CO.19437862.0000730

[16] Michael Gochfeld, Conrad D. Volz, Joanna Burger, Stephen Jewett, Charles W. Powers, \& Barry Friedlander (2006). Developing a health and safety plan for hazardous fieldwork in remote areas. Journal of occupational and environmental hygiene, 3(12), 671683. https://doi.org/10.1080/15459620601009201

[17] Mitropoulos, P., Abdelhamid, T. S., \& Howell, G. A. (2005). Systems model of construction accident causation. Journal of construction engineering and management, 131(7), 816-825. https://doi.org/10.1061/(ASCE)07339364(2005)131:7(816)

[18] Ophir Rozenfeld, Rafael Sacks, Yehiel Rosenfeld, Hadassa Baum, (2010). Construction job safety analysis. Science Direct, 48(4), 491-498. 
[19] Pheng, L. S., \& Shiua, S. C. (2000). The maintenance of construction safety: Riding on ISO 9000 quality management systems. Journal of quality in maintenance engineering, 6(1), 28-44. https://doi.org/10.1108/13552510010311327

[20] Pungvongsanuraks, P., Thitipoomdacha, C., Teyateeti, S., \& Chinda, T. (2010). Exploratory factor analysis of safety culture in the Thai construction industry. Proceedings of the 2010 international conference on engineering, project and production management, Thailand, 91-100.

[21] Reese, C. D., \& Eidson, J. V. (2006). Handbook of OSHA construction safety and health, $2^{\text {nd }}$ ed., CRC Press, pp. 12-14.

[22] Rwamamara, R. (2007). Risk assessment and analysis of workload in an industrialized construction process. Construction information quarterly, 9(2), 80-85.

[23] Salomone, R. (2008). Integrated management systems: Experiences in Italian organizations. Journal of cleaner production, 16(16), 1786-1806. https://doi.org/10.1016/j.jclepro.2007.12.003

[24] Sawyer, C.J., \& W.F. Martin, (2000). Health and Safety plans and contingency plans; In protecting personnel at hazardous waste sites, $3^{\text {rd }}$ ed., Boston: Butterworth Heinemann, pp. 420-440. https://doi.org/10.1016/B978-075067049-4/50015-1

[25] V. H. P. Vitharana, G. H. M. J. Subashi De Silva, \& Sudhira De Silva, (2015). Health hazards, risk, and safety practices in construction sites. Journal of the institution of engineers, 48(3), 35-44.

[26] Zolfagharian, S., Ressang, A., Irizarry, J., Nourbakhsh, M., \& Zin, R. M., (2011). Risk assessment of common construction hazards among different countries. 6th international conference on construction in the 21st century, Kuala Lumpur, Malaysia, 151-160. 